\title{
A study on the anti-allergic effects of the native probiotic isolates on $\beta$-histine hydrochloride induced mice model
}

\author{
K.M. Hossain ${ }^{1 *}$, A. Rahman ${ }^{2}$, S.M.M. Rahman ${ }^{1}$ and M.A. Jalil ${ }^{3}$ \\ ${ }^{1}$ Faculty Members, Biotechnology and Genetic Engineering Discipline, Khulna University, \\ Khulna-9208, Bangladesh. ${ }^{2}$ Microbiology Department, International Institute of Applied Science and \\ Technology, Rangpur. and former MS Research Fellow (CRG Project, BARC), Biotechnology and Genetic \\ Engineering Discipline, Khulna University, Khulna-9208, Bangladesh. ${ }^{3}$ Doctoral Research Fellow, \\ Biotechnology and Genetic Engineering Discipline, Khulna University, Khulna-9208, Bangladesh.
}

\begin{abstract}
This study aimed to screen anti-allergic effect of native probiotics isolated from yoghurt. The probiotic bacteria were isolated from the yoghurt sample collected from seven Divisions of Bangladesh. The isolated probiotic bacteria were then subjected to morphological and biochemical tests. These morphological and biochemical tests allowed us to ensure that the isolated bacteria were the probiotic type. Then animal trial was conducted using these probiotic isolates. In this study, mice were used as the animal model. At the end of the trial, the blood samples isolated from different mice groups were analyzed. It was observed that, the probiotic isolates had significant effect $(p<0.05)$ on the IgE level of the mice used in this experiment. The IgE levels of treatment group 1, treatment group 2 and treatment group 3 were found $(9.89 \pm 0.2 \mathrm{IU} / \mathrm{ml}),(5.88 \pm 0.14 \mathrm{IU} / \mathrm{ml})$ and $(3.14 \pm 0.11 \mathrm{IU} / \mathrm{ml})$, respectively. However, probiotic isolates had no significant effect $(\mathrm{p}>0.05)$ on the eosinophil count and peripheral lymphocyte count of the mice used this experiment. It is recommended that, probiotic yoghurt may be used for allergic patients to cure allergic reaction.
\end{abstract}

(Key words: Anti-allergic property, probiotic isolates, IgE level, eosinophil count, peripheral lymphocyte count)

\section{Introduction}

Probiotic is a Greek word. It has two parts "pro" and "biotic". "Pro" means "for" and "biotic" means life. So, the word probiotic stands for for life. As far literature can figure out Ferdinand Vergin coined this term in 1954 (Vergin, 1954). After about eleven years, this term was successfully described by two scientists named Stillwell and Lilly. These two scientists explained probiotics as the microbes that assist in the growth of other microbes existing in out digestive system (Lilly and Stillwell, 1965). This definition of probiotic bacteria was edited by several scientists for several times. For highlighting the source of such health beneficial bacteria, in the year of 1989, scientist Fuller forwarded that for a bacterium to be considered as a probiotic bacterium it should fulfill two conditions. First, it should be live and should play the health supportive roles in its host (Fuller, 1989). Again, Guarner and his fellow workers focused on the necessity of the proper concentration of probiotic bacteria with a view to obtaining their respective positive effects (Guarner and Schaafsma, 1998). According to the currently established definition probiotics are the viable strains of precisely selected microorganisms that, exert a positive physiological impacts on the host, when they are ingested in sufficient quantity (FAO, 2002). For example, Lactobacillus

*Corresponding author: kmhossainbt@yahoo.com.au

Bang. J. Livs. Res. Special Vol. 21-25, 2018: P. 36-44, ISSN 1022-3851 
casei, Lactobacillus bulgaricus, Lactobacillus plantarum, Lactobacillus rhamnosus, Lactobacillus acidophilus, Lactobacillus reuteri, Bacillus coagulans, Bifido- bacteria spp., Propionibacterium spp., Saccharomyces boulardii, Escherichia coli strain Nissle 1917 and Enterococcus faecium SF68 (Pandey et al., 2015; Chukeatirote, 2003).

Food allergens are the particular constituents of food items which are normally detected by humans' immune system and ultimately cause several allergicreactions (Boyce et al., 2011). Anaphylaxis is, no doubt, one of the most dangerous as well as potentially lethal allergic reactions. There are some other types of allergic reactions like gastrointestinal manifestations such as diarrhea, vomiting, abdominal pain, dysphagia, feeding disorders, reflux, bloody stools and growth failure; cutaneous manifestations such as eczema, flushing, angioedema, pruritus and urticaria; and respiratory manifestations such as dyspnea, wheezing, nasal congestion, rhinorrhea and sneezing (Nowak-Wegrzyn et al., 2016). Probiotic microorganisms have been assumed to activate of endogenous macrophages, inflection of regional and systemic release of Immunoglobulin A (IgA), and change of the levels of pro-inflammatory and anti-inflammatory cytokine, leading to the modulation of the response against allergens present in our day-to-day food items (Vandenplas et al., 2015). The term allergens refer to the antigens responsible for allergy (Johansson et al., 2004). These types of antigens are able to come in the contact of immune system by a number of ways. For example, respiration, ingestion, contact to skin and so on. Sometimes these allergens have direct access into our body due to an insect bites (Weiner et al., 2011). Atopy is a proclivity (either personal or familial), basically during childhood or adolescence, to produce immunoglobulin $\mathrm{E}$ ( $\mathrm{IgE}$ ) in response to the general exposure to allergens (usually proteins) and to exhibit typical symptoms such as rhino conjunctivitis, asthma and dermatitis oreczema. However, all the cases cannot be attributable to mechanisms related to IgE (Johansson et al., 2004; Brozek et al., 2010; Fiocchi et al., 2012).

The particular mechanisms underlining the favorable effects of probiotics on allergic reaction are not entirely known. Certain mechanisms have been investigated in vitro and in vivo. Moreover, to modulate the intestinal microflora, probiotics have been observed to improve the barrier function of the intestinal mucosa, reducing leakage of antigens through the mucosa and thereby exposure to them. Direct modulation of the immune system may be through the induction of anti-inflammatory cytokines or through increased production of secretory IgA. IgA will contribute to an exclusion of antigens from the intestinal mucosa. Further, enzymatic degradation of dietary antigens by enzymes from probiotics will reduce the load of and exposure to antigens. These and other mechanisms contribute to reduced exposure of the immune system to dietary antigens (Ouwehand, 2007).

A number of experimental works have presented the specific influences exerted by probiotic bacteria on the epithelial cells of intestine and immune cells with ant-allergic capability (Caramia et al., 2008). Literature reveals no such research work using native probiotics has been conducted so far. Therefore, the present research work was undertaken with the following objectives: 
(a) To measure the effects of isolated native probiotics on eosinophil count of mice. (b) To find out the effects of isolated native probiotics on the IgE level of mice. (c) To quantify the effects of isolated native probiotics on the peripheral lymphocyte count of mice.

\section{Materials and Methods}

Identified presumptive strains were used in various concentrations $(\mathrm{mL})$ after subdividing the mice into six groups namely negative control group (NCG), positive control group (PCG), standard group (SG), treatment group 1 (TG1), treatment group 2 (TG2) and treatment group 3 (TG3) for a 4-week trial (Table 1).

\section{Feeding procedure used in the mice trial}

In the negative control group only basal feed including whole maize, maize germ, cotton seed cake, soya beans and sunflower meal (chemically it is composed of starch, amino acids, fatty acids, and minerals) was provided from week 1 to week 4 . In case of positive control group, basal feed was given from week 1 to week 2 and a histamine (Minarinat the rate of $1 \%$ of body weight) along with basal feed was given from week 3 to week 4 .
For the standard group, basal feed was given from week 1 to week 2 and a histamine (Minarin, at the rate of $1 \%$ of body weight) and an anti-histamine (Fenadin, at the rate of $1 \%$ of body weight) were provided parallel with basal feed from week 3 to week 4 . For the treatment group 1, basal feed was given from week 1 to week 2 and a histamine (Minarin, at the rate of $1 \%$ of body weight) and probiotic yoghurt (at the rate of $0.5 \mathrm{~mL} / \mathrm{mouse}$ ) were provided parallel with basal feed from week 3 to week 4 . For the treatment group 2, basal feed was given from week 1 to week 2 and a histamine (Minarin at the rate of $1 \%$ of body weight) and probiotic yoghurt (at the rate of $1 \mathrm{~mL} /$ mouse) were provided parallel with basal feed from week 3 to week 4. For the treatment group 3, basal feed was given from week 1 to week 2 and a histamine (Minarinat the rate of $1 \%$ of body weight) and probiotic yoghurt (at the rate of $1.5 \mathrm{~mL} /$ mouse) were provided parallel with basal feed from week 3 to week 4 (Table 2). After then several physical symptoms like fatigue, loss of appetite, decreased motility, increased prone to any disease and death rate were observed.

Table 1. Number of mice used in the trial

\begin{tabular}{lc}
\hline \multicolumn{1}{c}{ Group } & No of mice \\
\hline Negative Control Group & 6 \\
Positive Control Group & 6 \\
Standard Group & 6 \\
Treatment Groups & 18 (three subgroups were made, each having 6 mice) \\
\multicolumn{1}{c}{ Total } & 36 (for a single experiment) \\
& Total 108 mice were used for three experiments \\
\hline
\end{tabular}


Table 2. Feeding pattern of the mice during the experimental trial

\begin{tabular}{|c|c|c|c|c|}
\hline Group & Week 1 & Week 2 & Week 3 & Week 4 \\
\hline $\begin{array}{c}\text { Negative Control } \\
\text { Group }\end{array}$ & $\begin{array}{l}\text { Basal feed }+ \\
\text { Pure drinking } \\
\text { water }\end{array}$ & $\begin{array}{l}\text { Basal feed }+ \\
\text { Pure drinking } \\
\text { water }\end{array}$ & $\begin{array}{l}\text { Basal feed + Pure } \\
\text { drinking water }\end{array}$ & $\begin{array}{c}\text { Basal feed + Pure } \\
\text { drinking water }\end{array}$ \\
\hline $\begin{array}{l}\text { Positive Control } \\
\text { Group }\end{array}$ & $\begin{array}{l}\text { Basal feed }+ \\
\text { Pure drinking } \\
\text { water }\end{array}$ & $\begin{array}{l}\text { Basal feed }+ \\
\text { Pure drinking } \\
\text { water }\end{array}$ & $\begin{array}{c}\text { Basal feed }+ \text { Pure } \\
\text { drinking water }+ \\
\text { Minarin }\end{array}$ & $\begin{array}{c}\text { Basal feed }+ \text { Pure } \\
\text { drinking water }+ \\
\text { Minarin }\end{array}$ \\
\hline Standard Group & $\begin{array}{l}\text { Basal feed }+ \\
\text { Pure drinking } \\
\text { water }\end{array}$ & $\begin{array}{l}\text { Basal feed }+ \\
\text { Pure drinking } \\
\text { water }\end{array}$ & $\begin{array}{c}\text { Basal feed }+ \text { Pure } \\
\text { drinking water }+ \\
\text { Minarin }+ \text { Fenadin }\end{array}$ & $\begin{array}{c}\text { Basal feed + Pure } \\
\text { drinking water }+ \\
\text { Minarin }+ \text { Fenadin }\end{array}$ \\
\hline Treatment Group 1 & $\begin{array}{l}\text { Basal feed }+ \\
\text { Pure drinking } \\
\text { water }\end{array}$ & $\begin{array}{l}\text { Basal feed }+ \\
\text { Pure drinking } \\
\text { water }\end{array}$ & $\begin{array}{c}\text { Basal feed }+ \text { Pure } \\
\text { drinking water }+ \\
\text { Minarin + Probiotic } \\
\text { yoghurt }(0.5 \\
\mathrm{mL} / \text { mouse })\end{array}$ & $\begin{array}{c}\text { Basal feed }+ \text { Pure } \\
\text { drinking water+ } \\
\text { Minarin + Probiotic } \\
\text { yoghurt }(0.5 \\
\mathrm{mL} / \text { mouse })\end{array}$ \\
\hline Treatment Group 2 & $\begin{array}{l}\text { Basal feed }+ \\
\text { Pure drinking } \\
\text { water }\end{array}$ & $\begin{array}{l}\text { Basal feed }+ \\
\text { Pure drinking } \\
\text { water }\end{array}$ & $\begin{array}{c}\text { Basal feed + Pure } \\
\text { drinking water+ } \\
\text { Minarin + Probiotic } \\
\text { yoghurt (1.0 } \\
\mathrm{mL} / \mathrm{mouse})\end{array}$ & $\begin{array}{c}\text { Basal feed + Pure } \\
\text { drinking water+ } \\
\text { Minarin + Probiotic } \\
\text { yoghurt (1.0 } \\
\mathrm{mL} / \text { mouse) }\end{array}$ \\
\hline Treatment Group 3 & $\begin{array}{l}\text { Basal feed }+ \\
\text { Pure drinking } \\
\text { water }\end{array}$ & $\begin{array}{l}\text { Basal feed }+ \\
\text { Pure drinking } \\
\text { water }\end{array}$ & $\begin{array}{c}\text { Basal feed + Pure } \\
\text { drinking water+ } \\
\text { Minarin + Probiotic } \\
\text { yoghurt (1.5 } \\
\mathrm{mL} / \text { mouse) }\end{array}$ & $\begin{array}{c}\text { Basal feed + Pure } \\
\text { drinking water+ } \\
\text { Minarin + Probiotic } \\
\text { yoghurt (1.5 } \\
\text { mL/mouse) }\end{array}$ \\
\hline
\end{tabular}

\section{Eosinophil and peripheral lymphocyte level count}

At first the mice were slaughtered with sterile scalpel blade and the blood drained out from the jugular vein was collected in Eppendorf tubes. The tubes were marked properly and then kept in the ice. The blood was gently mixed in the EDTA vial, so that the cells mixed well with plasma. The blood was drawn in the WBC pipette up to mark 1. Then the excess blood was wiped off from sides of the tip of the pipette. Then the tip was dipped of the pipette in the Dunger's fluid and the fluid was drawn up to mark 11. The dilution was 1 in 10 . Holding the pipette horizontally in its long axis, it was rotated slowly to ensure thorough mixing of blood and diluent. This was facilitated by the white bead in the bulb. The cover slip was placed on the cleaned ruled area of the counting chamber. The first 2 to 3 drops (since the fluid has not mixed with blood) of WBC fluid was discarded from the pipette. The chamber was changed by placing the tip of the pipette just beside the cover slip and fluid flows under it by capillary action. Allowed till the counting chamber is just filled. The Eosinophil and Peripheral Lymphocytes were allowed for 5 minutes to settle in the chamber. The number of those blood cells in the 4 corner squares was counted using a low power objective. 
Eosinophil and Peripheral Lymphocytes were identified and the count was done within 30 minutes.

Absolute Eosinophil Count $($ AEC $)=($ Total number of Eosinophil in 4 squares $) \times 25$

Peripheral Lymphocyte Count $($ PLC $)=($ Total number of Peripheral Lymphocyte in 4 squares) $\times 25$

\section{IgE level count}

All the reagents includingzero buffer, enzyme conjugate, TMB reagent, stop solution and distilled wateras well as the samples were brought at room temperature. A $20 \mu \mathrm{L}$ sample/standard was added in each well. Then $100 \mu \mathrm{L}$ zero buffer was added in each well and mixed well for 10 seconds. The mixture was kept at room temperature for 30 minutes. The well content was discarded and wells were washed 5 times with distilled water. The droplets of water were from the well using absorbent paper. $50 \mu \mathrm{L}$ enzyme conjugate was added to each well and mixed well for 10 seconds. The mixture was kept at room temperature for 30 minutes. The well content was discarded and wells were washed 5 times with distilled water. The droplets of water were from the well using absorbent paper. $100 \mu \mathrm{L}$ TMB reagent was added to each well and mixed well for 5 minutes. The mixture was kept at room temperature for 20 minutes in dark. Then $100 \mu \mathrm{L}$ stop solution was added to each well and mixed well for 30 seconds. The reading was taken by ELISA reader at $450 \mathrm{~nm}$ wavelength within 15 minutes.

\section{Results and Discussion}

Immunoglobulin E (IgE) levels, eosinophil count and peripheral lymphocyte count of the treatment groups with the negative, positive and standard control group have been presented in Figure 1,2 and 3. IgE levels were expressed as International Units per Milliliter (IU/mL). Six mice were used for each group in a single experiment. Values are presented as mean $\pm \mathrm{SD}$ (bars), $\mathrm{n}=3$.

Actually, allergy triggered by IgE may provide a beneficial function to the host; the typical allergic reactions of mucus secretion, sneezing, itching, coughing, bronchoconstriction, tear production, inflammation, vomiting and diarrhoea are all mechanisms that expel allergenic proteins from the body. In this study, three parameters were considered. They are - IgE level, eosinophil count and peripheral lymphocyte count. From the Figure 1, it has been found that, the probiotic yoghurt had significant effect on the $\operatorname{IgE}$ level of the mice used in this experiment. The negative control group had the lowest IgE level $1.36 \pm 0.06 \mathrm{IU} / \mathrm{ml}$, where the positive control group had the highest value of $\operatorname{IgE}$ level $78.58 \pm 1.48 \mathrm{IU} / \mathrm{ml}$. The standard group accounted for $1.51 \pm 0.04$ $\mathrm{IU} / \mathrm{ml}$ of $\mathrm{IgE}$ concentration, while in treatment group 1,2 and 3 , the $\operatorname{IgE}$ concentration was found $9.89 \pm 0.2,5.88 \pm 0.14$ and $3.14 \pm 0.11 \mathrm{IU} / \mathrm{ml}$, respectively. There are some variations in the results of this current study with the result of similar studies including the study of Kim et al. (2005) in which the total serum IgE levels in the three treated groups were not significantly different at week 7 from the levels in mice $(295 \pm 25 \mathrm{ng} \mathrm{ml} / 1$; BGN4, $389 \pm 31 \mathrm{ng} \mathrm{ml} / 1$; L. casei, $333 \pm 69 \mathrm{ng} \mathrm{ml} / 1$; E. coli, $314 \pm 78$ $\mathrm{ng} \mathrm{ml} / 1$ ). These variations may be due to different sample size, probiotic content of the yoghurt and the process of probiotic 
ingestion. In the study of Kim, the sample size was 30 and in the current study, the sample size was 36 . In the study of Kim, bacteria were provided in powder form but in the current study, the bacteria were provided through yoghurt.

For over 100 years, the eosinophil has been associated with allergic disease. Eosinophils play a key role in the symptoms of asthma and allergies, such as hay fever. The effector functions of eosinophils appear to be derived primarily from release of lipid mediators and proteins, including cytokines and granule proteins. Eosinophil degranulation results in the release of several cytotoxic cationic granule proteins. In this current study, the eosinophil count of the negative control group was $2.83 \pm 0.05 \%$ while in positive control group was $3 \pm 0.03 \%$ and in the standard group it was found $2.17 \pm 0.03 \%$.On the other hand, the treatment group 1, 2 and 3 had $2.33 \pm 0.04,2.5 \pm 0.04$ and $1.83 \pm 0.03 \%$ of eosinophil, respectively (Figure 2). There are some variations in the results of this current study with the result of other similar studies. For example, the study of Zhong et al. (2012) where the negative control group showed the eosinophil count $30.73 \pm 10.3$, the positive control group showed $75.2 \pm 13.7$ and the probiotic treated group $33.8 \pm 9.1$.

When lymphocytes make a mistake it can create an allergic response. Lymphocytes act like traveling customs agents. When a lymphocyte encounters a particle or cell with surface marker molecules that identify it as a foreign invader and thereby the allergic reaction is triggered. The value of peripheral lymphocyte count was observed $33.67 \pm 1.02 \%$ in case of negative control group whereas, the positive control group had $22.67 \pm 0.88 \%$ andthe standard group had $22.83 \pm 0.81 \%$. The peripheral lymphocyte counts of treatment group 1, treatment group 2 and treatment group 3 were found $34.33 \pm 1.12,32 \pm 1.05$ and $34.33 \pm 1 \%$, respectively (Figure 3 ). It was observed that, the probiotic yoghurt increased the level of peripheral lymphocyte at the significant level $(p<0.05)$. Here, it was observed that, the probiotic yoghurt had no significant effect on the peripheral lymphocyte count of the mice used this experiment. There are some variations in the results of this current study with the result of similar studies like the study conducted by Victoria et al. (1999). In the study conducted by Victoria, the value of peripheral lymphocyte count was $48.46 \pm 1.07 \%$ in case of negative control group but the positive control group had $12.55 \pm 0.59 \%$. The standard group had $90 \pm 0.07 \%$ and the peripheral lymphocyte counts of treatment group was $55.23 \pm 1.2 \%$. All such variations may be due to different diet, different probiotic content of the yoghurt, and difference in the process of probiotic ingestion. In the study of Zhong and Victoria the mice were provided with OVA-free rodent diet but the mice was provided normal rodent diet. In the study of Zhong, the probiotic dose was $0.5 \times 109$ $\mathrm{cfu} / \mathrm{ml}$ but in the present study the ingested dose was $1.0 \mathrm{X} 109 \mathrm{cfu} / \mathrm{ml}$. In the study of Victoria, the probiotic bacteria was ingested through phosphate buffer saline and in the current study probiotic bacteria was ingested through yoghurt. 


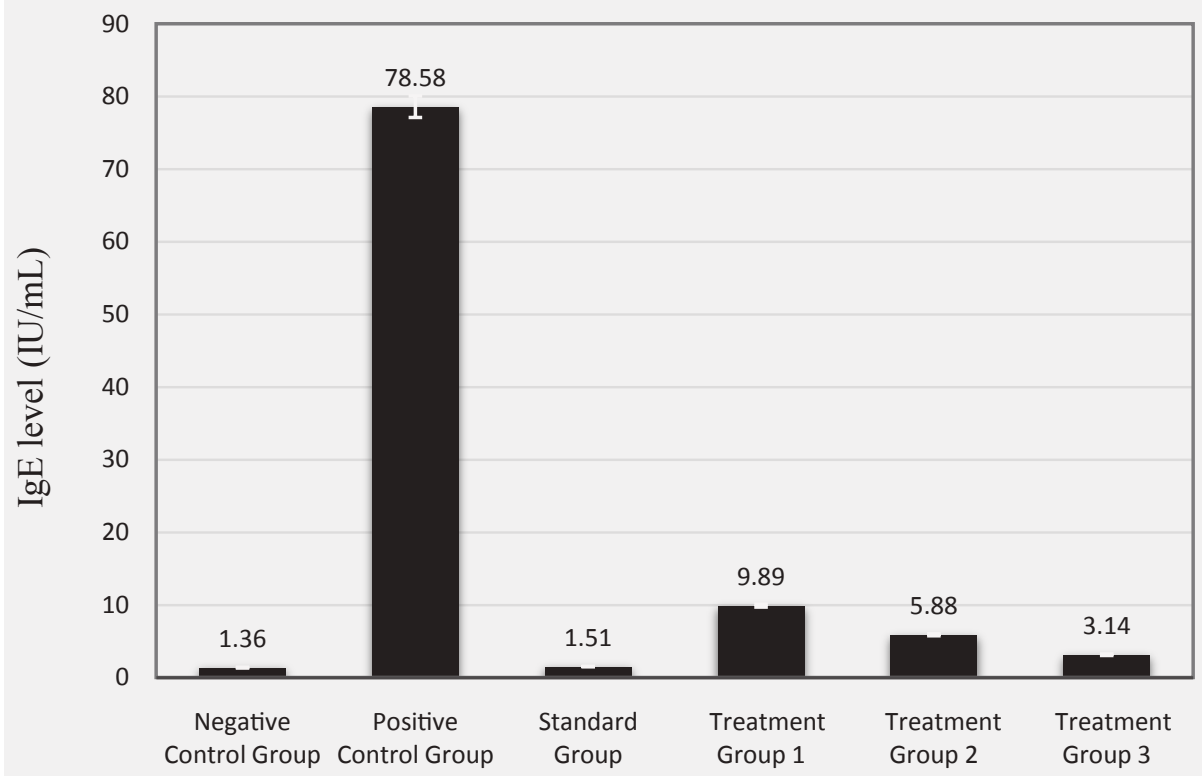

Figure 1.Comparison of Immunoglobulin E (IgE) levels of the treatment groups with the negative, positive and standard control group.

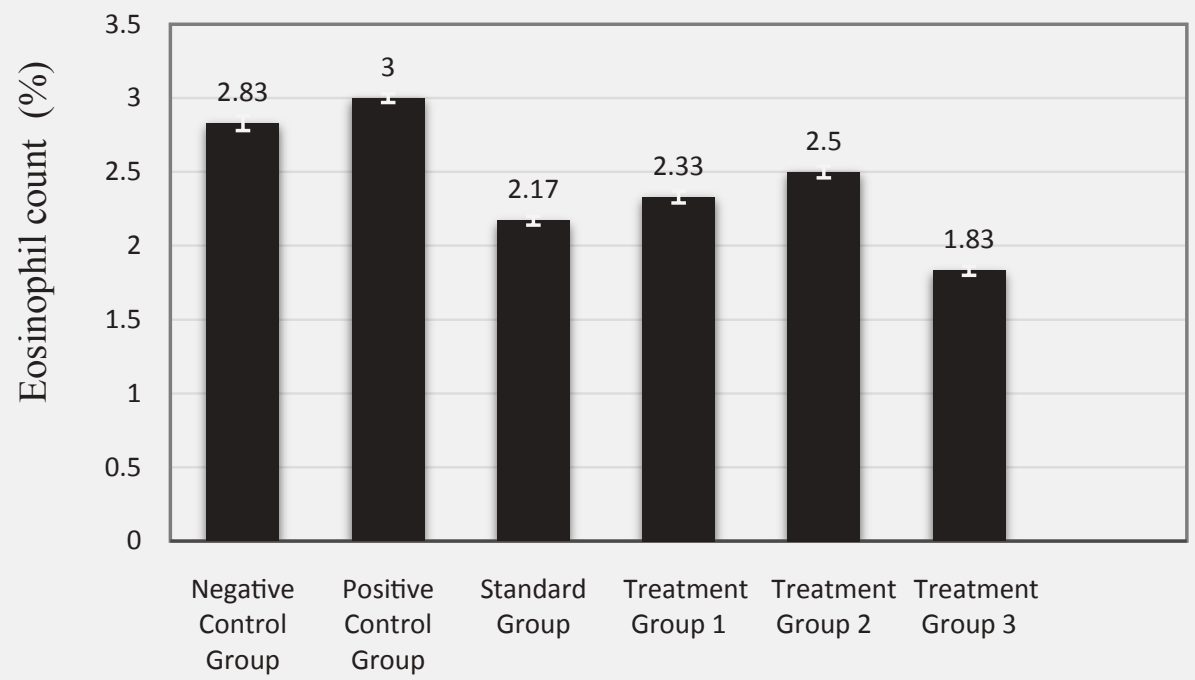

Figure 2.Comparison of eosinophil count of the treatment groups with the negative, positive and standard control group. 


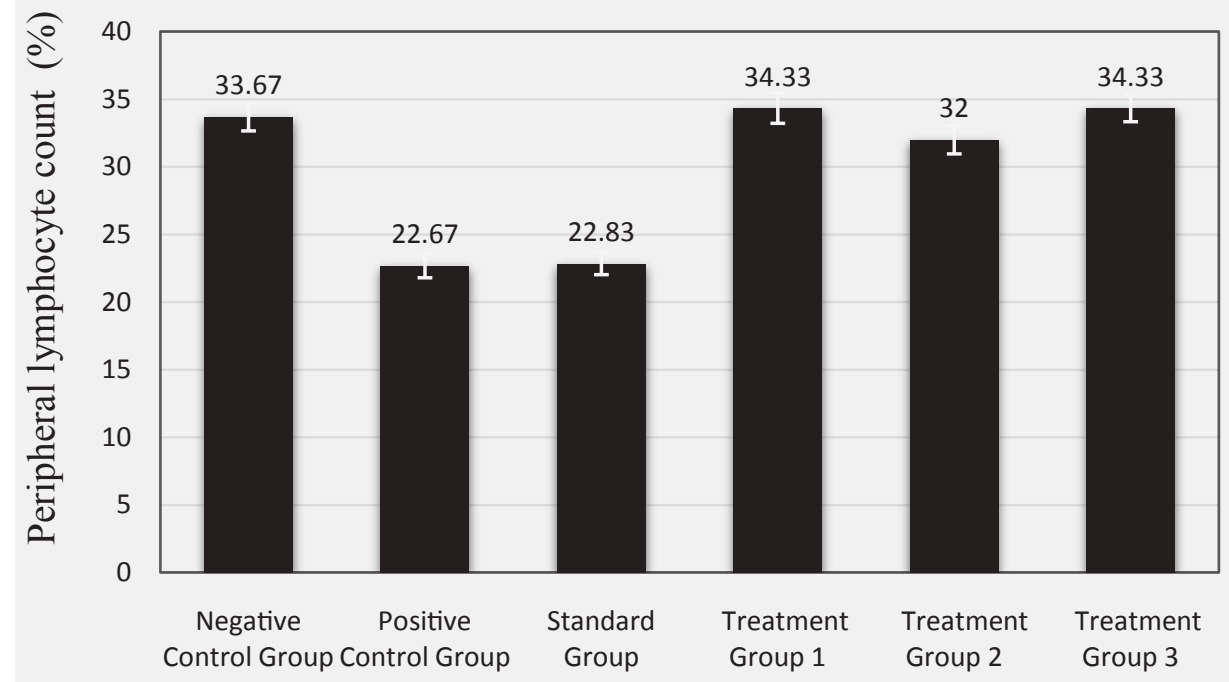

Figure 3. Comparison of peripheral lymphocyte count of the treatment groups with the negative, positive and standard control group.

\section{Conclusion}

It can be concluded that, the presumptive probiotic strains of Lactobacillus has profound effect on the IgE level of mice but Lactobacillus has not any significant effect on the eosinophil level and peripheral lymphocyte level. Therefore, Lactobacillus may be used as an agent to prevent allergy. This research work will serve to present Lactobacillus as a potential agent to fight against allergy. It can be expected that in near future it will be possible to use Lactobacillus not only in yoghurt but also in other food items for human consumption as antiallergen. However, further investigations in this area along with research interventions would be worthy.

\section{Acknowledgement}

The authors are grateful to the authority of National Agricultural Technology Program-
Phage II (NATP-2), Project Implementation Unit, Bangladesh Agricultural Research Council (BARC) for providing funding under Competitive Research Grant (CRG) by the World Bank.

\section{References}

Boyce, J.A., Assa'ad, A., Burks, A.W., Jones, S. M., Sampson, H.A., Wood, R.A., Plaut, M., Cooper, S.F. and Fenton, M.J. 2011. Guidelines for the diagnosis and Management of Food Allergy in the United States: summary of the NIAID-sponsored expert panel report. Nutri. Res., 31:61-75.

Brozek, J. L., Bousquet, J., Baena-Cagnani, C. E., Bonini, S., Canonica, G.W., Casale, T.B., van Wijk, R.G., Ohta, K., Zuberbier, T. and Schünemann, H.J. 2010. Allergic Rhinitis and its Impact on Asthma (ARIA) guidelines: 2010 revision. Journal of Allergy and Clinical Immunology, 126(3): 466-476.

Caramia, G., Atzei, A. and Fanos, V. 2008. Probiotics and the skin. Clinics in 
Dermatology, 26 (1): 4-11.

Chukeatirote, E. 2003. Potential use of probiotics.

Songklanakarin Journal of Science and Technology, 25: 275-282.

Fiocchi, A., Burks, W., Bahna, S.L., Bielory, L., Boyle, R.J., Cocco, R., Dreborg, S., Goodman, R., Kuitunen, M., Haahtela, T., Heine., R.G., Lack, G., Osborn, D.A., Sampson, H., Tannock, G.W. and Lee, B.W. 2012. Clinical use of probiotics in pediatric allergy (CUPPA): a World Allergy Organization position paper. World Allergy Organization Journal, 5 (11): 148-167.

Food and Agriculture Organization (FAO) 2002. Guidelines for the Evaluation of Probiotics in Food; Report of a Joint FAO/WHO Working Group on Drafting Guidelines for the Evaluation of Probiotics in Food; FAO: London, Ontario, Canada, 30 April-1 May 2002.

Fuller, R. 1989. Probiotics in man and animals. Journal of Applied Microbiology, 66: 365-378.

Guarner, F. and Schaafsma, G. J. 1998. Probiotics. International Journal of Food Microbiology, 39: 237-238.

Johansson, S.G., Bieber, T., Dahl, R., Friedmann, P. S., Lanier, B.Q., Lockey, R.F., Motala, C., Ortega Martell, J. A., Platts-Mills, T. A., Ring, J., Thien, F., Van Cauwenberge, P.and Williams, H. C. 2004. Revised nomenclature for allergy for global use: report of the Nomenclature Review Committee of the World Allergy Organization, October 2003. Journal of Allergy and Clinical Immunology, 113: 832-836.

Kim, H., Kwack, K., Kim, D.Y. and Ji, G.E. 2005. Oral probiotic bacterial administration suppressed allergic responses in an ovalbumin-induced allergy mouse model. FEMS Immunology and Medical Microbiology, 45: 259-267.
Lilly, D.M. and Stillwell, R.H. 1965. Probiotics: Growth promoting factors produced by microorganisms. Science,147: 747-748.

Nowak-Wegrzyn, A., Sampson, H.A. and Sicherer, S.H. 2016. Food allergy and adverse reactions to foods. In: Nelson textbook of pediatrics. Kliegman, R.M., Stanton, B.F., St Geme, J.W., Schor, N.F. (eds.). 20th edition. Philadelphia: Elsevier. pp. 1137-1143.

Ouwehand, A.C. 2007. Antiallergic Effects of Probiotics. Journal of Nutrition. 137: 794-797.

Pandey, K.R., Naik, S.R. and Vakil, B.V. 2015. Probiotics, prebiotics and synbiotics - a review. Journal of Food Science and Technology, 52(12): 7577-7587.

Vandenplaset, Y., Huys, G. and Daube, G. 2015. Probiotics: an update. Journal of Pediatrics, 91(1): 6-21.

Vergin, F. 1954. Anti-und Probiotica. Hipokrates, 25: 116-119.

Victoria, M., Simon, T., Ustunol, Z. and Pestka, J. J. 1999. Effects of lactic acid bacteria ingestion on basal cytokine mRNA and immunoglobulin levels in the mouse. Journal of Food Protection,62(3):287-291.

Weiner, H.L., Da Cunha, A.P., Quintana, F. and $\mathrm{Wu}, \mathrm{H} .2011$. Oral tolerance. Immunological Reviews,241: 241-259.

Zhong, Y., Huang, J., Tang, W., Chen, B. and Cai, W. 2012. Effects of probiotics, probiotic DNA and the $\mathrm{CpG}$ oligodeoxynucleotides on ovalbumin-sensitized Brown-Norway rats via TLR9/NF-jB pathway. FEMS Immunology and Medical Microbiology,66: 71-82. 